\title{
Response of a Natural Marsh to Chemical and Biological Inputs of Eutrophic Waters (Saladas, Corrientes, Argentina)
}

\author{
Neiff, J. J.; Patiño, C. A.; Poi de Neiff, A. S.; Zalocar de Domitrovic, Y.; and Frutos, S. M. \\ Centro de Ecologia Aplicada - Casilla de Correo 222 \\ 3400 Corrientes, Argentina
}

Recebido: 12/12/00 - revisão: 13/12/01 - aceito: 09/07/02

\begin{abstract}
Soto marsh is a non forested inland freshwater wetland with a bumid subtropical weather and fed by rains and domestic wastes through the Soto lake. Main hydrological characteristics and the composition of vegetation and soil through which the water circulates are described. Chemical and biological conditions of water entering and leaving the marsh during dry and rainy periods were compared. Passage through the marsh reduces $\mathrm{BOD}_{5}$ by $64 \%$, producing an average effluent of $2.2 \mathrm{mg} . \mathrm{l}^{1}$. Average chlorophyll " $a$ " concentration was reduces by $76 \%$ in relation to value recorded at inflow. During the rainy period, the concentration of chlorides, calcium, potassium and sodium was lower in the leaving of the marsh while in the dry period the concentration of anions and cations was very variable. Our results indicate that Soto marsh functions as a source of nutrients (phosphorus and ammonium) when the concentration of organic matter was high and the concentration of dissolved oxygen was low. In the Soto lake and at inflow of the Soto marsh, phytoplanton was dominated by cyanophyte, specially colonies of Microcystis aeruginosa while at the marsh outlet there were higher proportion of other algae. After passage through the marsh zooplankton abundance decreased specially rotifers populations characteristic of eutrophic environments. Comparing the same vegetation (Salvinia biloba), the number of invertebrates associated with the plants was higher in the lake than in the marsh. This decrease was more marked during the rainy period
\end{abstract}

Key Words: marsh; inputs; chemical; biological.

\section{INTRODUCTION}

Soto marsh is one of the numerous wetlands occupying more than a fifth of the province of Corrientes (Argentina). Marshes are wetlands with a very slight slope, densely vegetated with plants (geophytes) which decompose slowly, originating the formation of soils with a superficial organic horizon (Neiff, 1997). The water has a permanent acid condition, high transparency, brown colour and is poor in suspended inorganic matter.

Even today, there is a marked defficiency in the information related to the functions and importance of flooded areas in South America, which is more evident when looking at the quantity of publications available on lacustrine environments. In most cases, society perceives marshes as "low value lands", due to difficulties for land cultivation, cattle raising or the permanent settlement of urban centres.

In many countries (specially in the northern hemisphere, where wetlands have been strongly interfered since the first decades of this century) this situation has changed, with a clear awareness of the functions and importance of these ecosystems (Brinson et al., 1981; Gopal, 1998; Mitsch \& Gosselink, 1993; Mitsch et al., 1988). The studies carried out have demonstrated the usefulness of restoring drained wetlands (Mitsch \& Gosselink, 1993; Hey et al., 1989) and also the possibility of using natural wetlands for recreation, to maintain biodiversity and other useful services to people (Mitsch et al., 1988). There are also succesful experiences in the construction of wetlands for treatment of pluvial and waste urban effluents (Bastian et al., 1989; Giovannini \& Motta Marques, 1998a, b; Salati et al., 1998).

In this study, we compared influent and effluent conditions of the Soto marsh, which receives wastewater from an eutrophic lake. In order to measure the response of the marsh, physical, chemical and biological changes in the water quality were followed during dry and rainy periods. Main hydrological characteristics of the marsh and composition of vegetation and soil through which the water circulates are described.

\section{METHODS}

A topographic synopsis was carried out based on a planialtimetric profile, which crosses transversely the study area, from the border of the Ambrosio stream up to a little more south of the National Route 118 (Figure 1). The 2960-6 Topographic Map of the Military Geographic Institute (MGI), Saladas, province of Corrientes, scale 1:100,000 was used, considering as an altimetric reference the intersection of the profile layout with level curves and fixed points marked out by the MGI.

The map is complemented by two transections within the Soto marsh, in which depth of the water lamina was measured. Transections (Figure 1) are perpendicular to the channel which crosses the marsh in a southern direction from the outlet of the Soto lake (near the Provincial Route 13) up to the bridge over the National Route 118. 


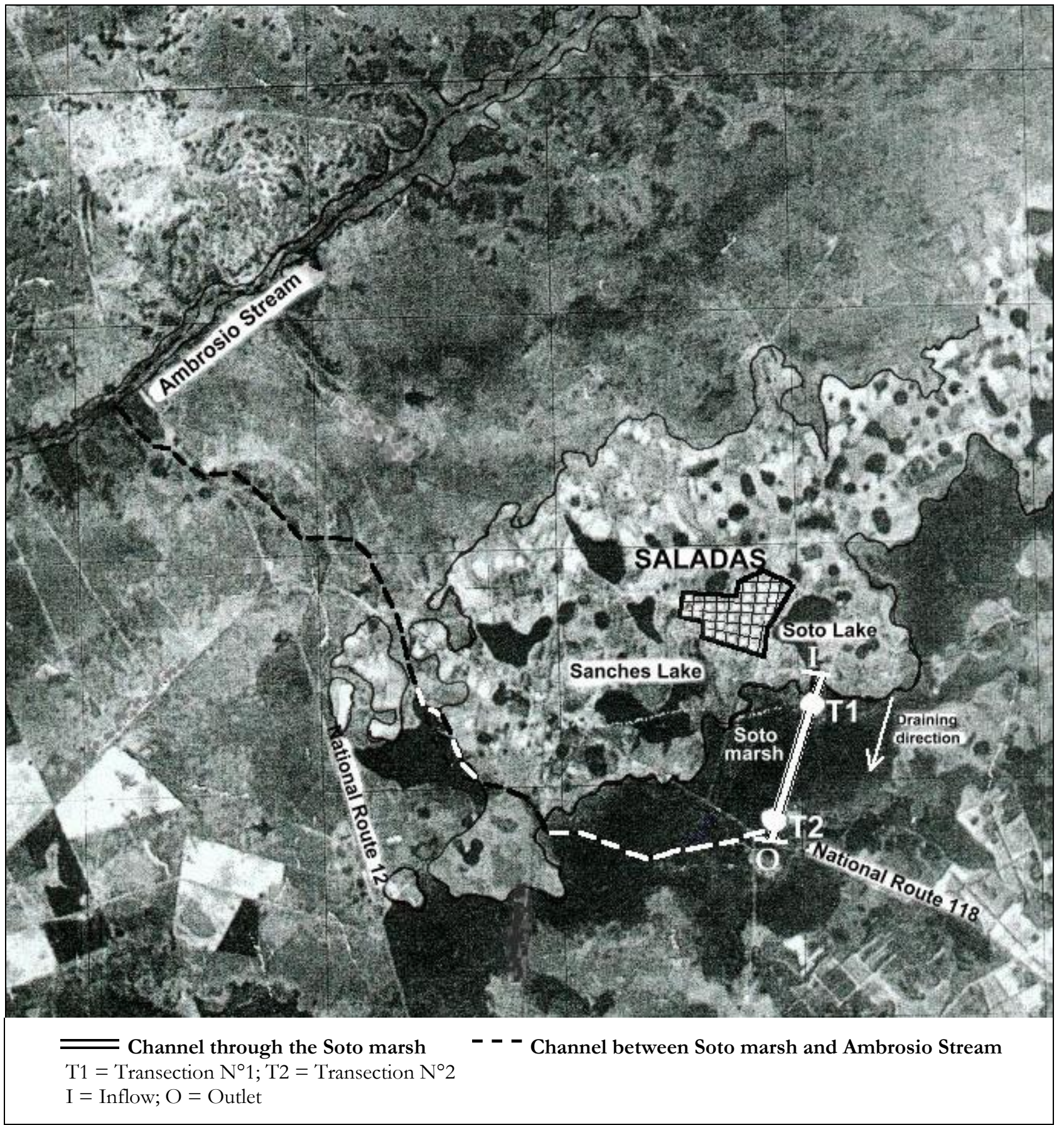

Figure 1. Map of the area studied (Source: topographic map of IGM-2960-6 Saladas).

Physical, chemical and biological data were taken at the inflow and oulet of the Soto marsh (T1 and T2 in Figure 1) in five occasions between March 1998 and August 1999. At each site, water temperature, electric conductivity, dissolved oxygen concentration and $\mathrm{pH}$ were recorded in the field using a conductimeter, a portable polarographic oximeter and a digital $\mathrm{pH}$ meter. Samples for laboratory chemical analyses were taken at the same sites and transported cooled to the laboratory. Metal concentration was measured by atomic absorption spectrophotometry and concentrations of nitrites, nitrates, ammonium and total phosphorus were measured by colorimetry (APHA, 1975).

Content of organic matter in the water was indirectly assessed through the capacity to oxidize organic compounds (COD) by reaction with potassium dichromate (APHA, 1975). Quantity of oxygen required for biochemical degradation of organic material (BOD) was measured at $20{ }^{\circ} \mathrm{C}$ after incubating the water, previously saturated with oxygen, for five days (APHA, 1975). 


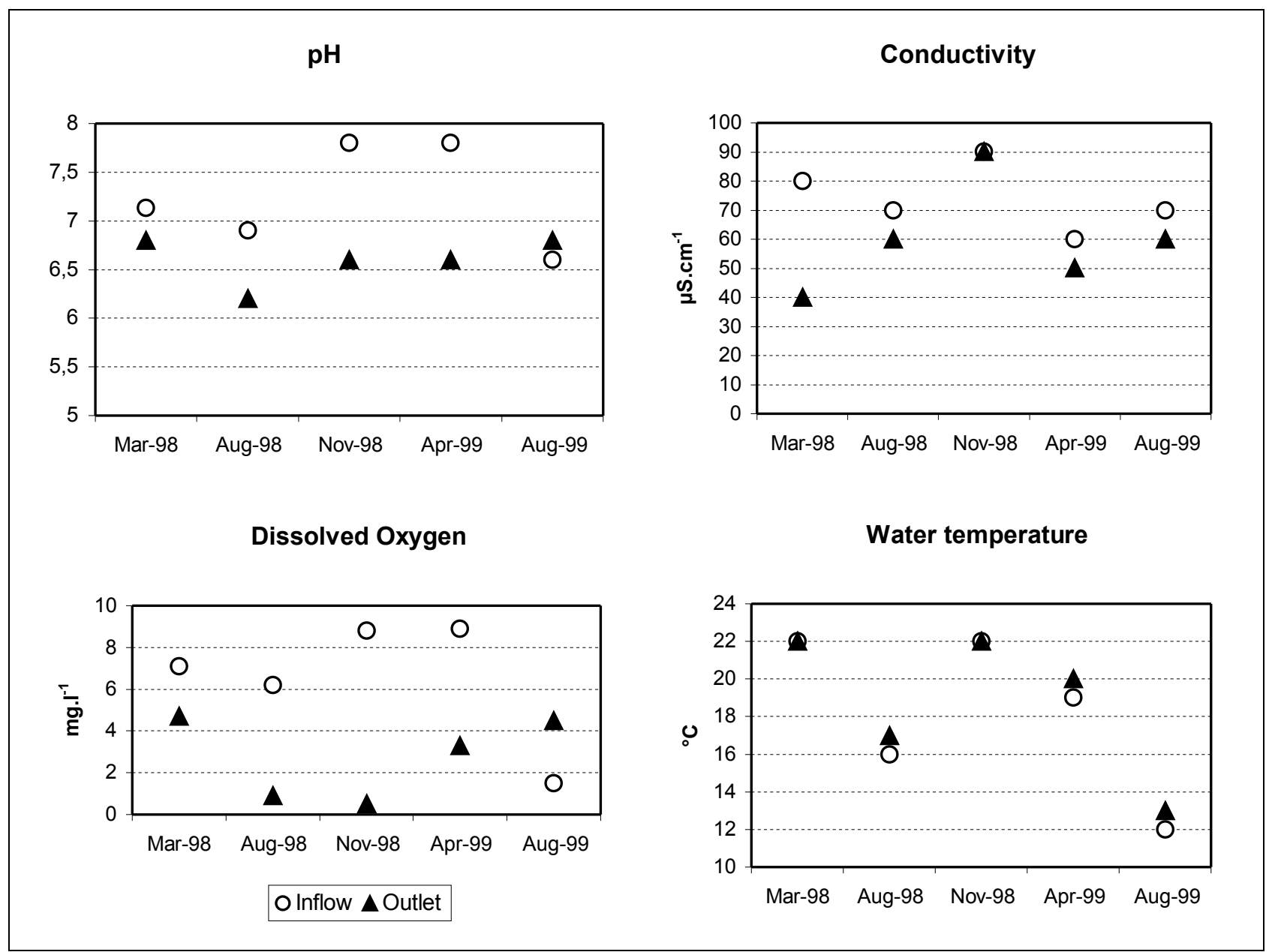

Figure 2. Soto marsh influent and effluent water quality; period March 1998 to August 1999.

Biomass of planktonic algae was estimated through chlorophyll a concentration, measured by the fluorometric method (APHA, 1975) in $500 \mathrm{ml}$ water samples transported cooled to the laboratory. Analyses were carried out after $12 \mathrm{~h}$ maceration of algae, retained in GFC glass fiber filters of $0.7 \mu \mathrm{m}$, using $96 \%$ acetone.

For plankton analysis, samples taken using a battery pump in the Soto lake and in the channel which crosses the marsh (inflow and outlet of the wetland) were filtered with $25 \mu \mathrm{m}$ (phytoplankton) and $53 \mu \mathrm{m}$ (zooplankton) nets. Phytoplankton quantification (number of algae per $\mathrm{ml}$ ) was carried out using an inverted microscope following the method propose by Utermöhl (1958). Zooplankton density (number of individuals per liter) was estimated through subsample counts in Sedwick Rafter chambers.

Aquatic plant constituted by associations of Salvinia biloba with Oplismenopsis najada, Hydrocleis nymphoides and Egeria naias were sampled in the littoral area of the Soto lake and at the outlet of the Soto marsh to determine vegetation biomass and density of associated invertebrates. Samples were collected by enclosing $962 \mathrm{~cm}^{2}$ of Salvinia biloba stands with a $250 \mu \mathrm{m}$ mesh net and were fixed in the field with $4 \%$ formaldehyde. The most cost effective sam- pler size for phytofauna populations densities of 10,000 ind. $\mathrm{m}^{-2}$ is about $900 \mathrm{~cm}^{2}$ with three replications (Downing \& Cyr, 1985). In the laboratory, the plants were washed to detach the invertebrates. Water coming from the washing was filtered using $1 \mathrm{~mm}, 500 \mu \mathrm{m}$ and $250 \mu \mathrm{m}$ sieves for a better separation of plant rests. Total density, expressed as number of individuals by square meter of surface covered by the plants, corresponds to the addition of the three fractions. The cleaned, plants were dried to constant weight at $105^{\circ} \mathrm{C}$ for $96 \mathrm{~h}$. Biomass of the sample (average of three) was converted to a square meter.

In order to relate ammonium concentration with oxygen content Spearman rank correlation was applied (Steel \& Torrie, 1985).

\section{SITE DESCRIPTION}

\section{Weather}

Soto marsh (28 $\left.18^{\prime} 54^{\prime \prime} ; 58^{\circ} 36^{\prime} 41^{\prime \prime} \mathrm{W}\right)$ has a humid subtropical weather, with an annual mean temperature of $23^{\circ} \mathrm{C}$ and absolute extremes of $-1{ }^{\circ} \mathrm{C}$ and $42{ }^{\circ} \mathrm{C}$ during the 
Table 1. Chemical characteristics of water samples at Soto marsh.

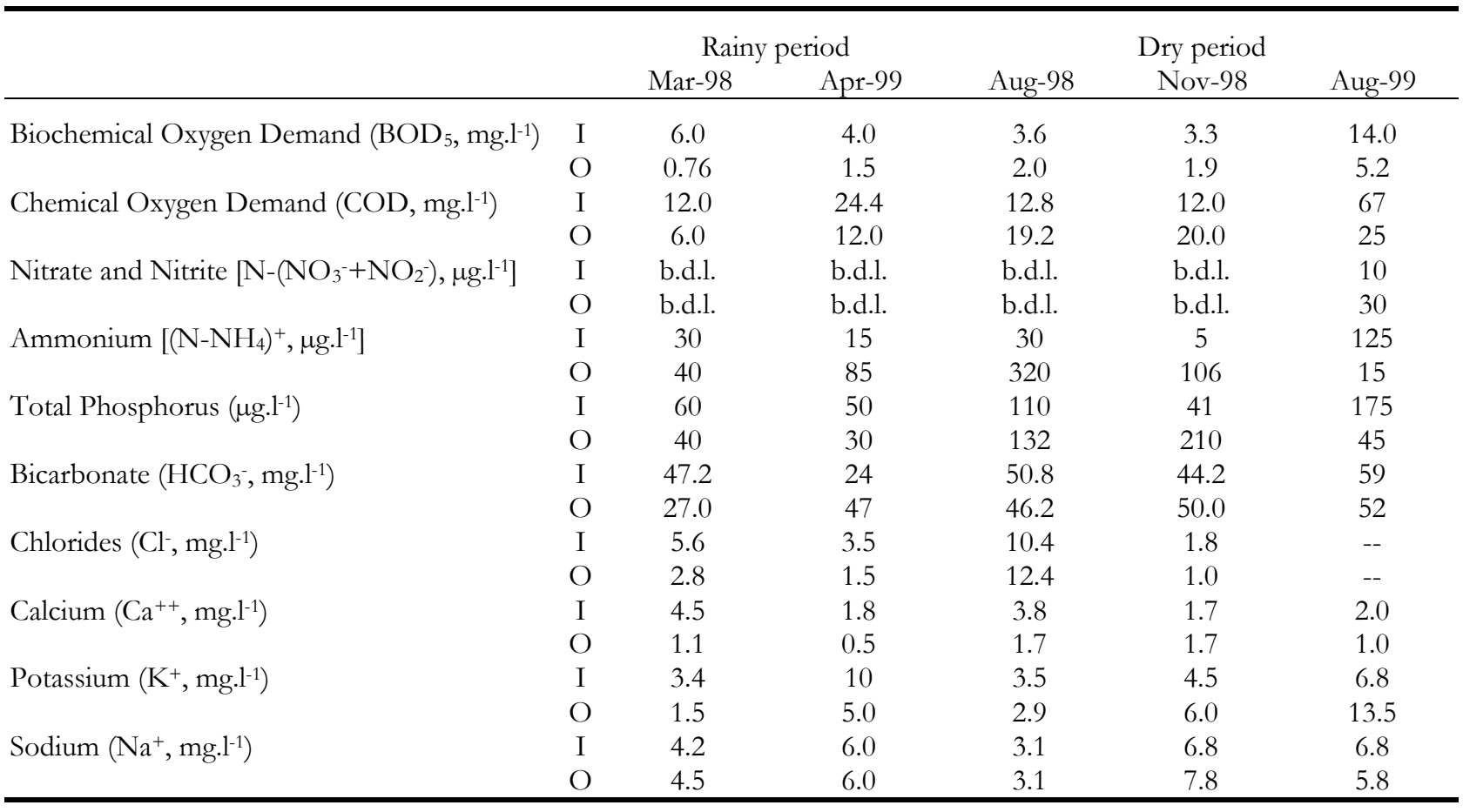

b.d.l. = below detection limit; $\mathrm{I}=$ Inflow; $\mathrm{O}=$ Outlet.

study period. Rains reached $1,879 \mathrm{~mm}$ during 1998 , from which $1,233 \mathrm{~mm}$ corresponded to the first four months of the year. March 1998, with $371.4 \mathrm{~mm}$ of rain, represents a prolonged rainy period, attributed to the "El Niño" event by Núñez \& Vargas (1998), which began in spring (September-December) 1997. Between May and December 1998 there was a period with a marked decrease in rains. In April 1999, another rainy period of shorter duration and magnitude than that of 1998 was recorded. Since May 1999, the marsh gradually decreased its depth due to a prolonged period of scarce rain contributions.

\section{Hydrology}

The marsh is mainly fed by local rains, which enter superficially from surrounding areas, and by domestic wastes through the Soto lake. Waters enter the marsh through a channel, spread through a $5 \mathrm{~km}$ length, $2 \mathrm{~m}$ width plain and join in a collector, the Ambrosio stream (Figure 1). There is an additional input of chemical substances, coming from a waste effluents treatment plant in Saladas city. During the dry period, these effluents are isolated within the discharge channel built for that purpose. In the flood period, effluents of treatment plant disperse through the wetland.

The marsh integrates then a very slow way of drainage beginning in Saladas city (70 $\mathrm{m}$ a.s.l.) and draining towards the Soto lake, then to the marsh and finally into the Paraná river. During the rainy period, floods of this lake enter the Soto marsh, located at $67 \mathrm{~m}$ a.s.l. Water is slowly distributed over a surface of approximately 980 hectares, accumulating a lamina of $40-70 \mathrm{~cm}$ depth at the end of the rainy period. The mean slope of the ground along this drainage way is 1:3000.

In this condition the equations used to calculated residence time in constructed wetlands (Watson \& Hobson, 1989) is not easily applied (Mitsch \& Gosselink, 1993).

In 1999 after the rainy period occurred in April, the duration of the flood phase was estimated in aproximately 30 days. For that purpose the water level in the oulet of the channel at the beginning and at the end of the flood phase were measured.

\section{Topography}

Along $12 \mathrm{~km}$ which separate Saladas city (highest sector) from the Ambrosio stream (lowest area), the slope changes from $70 \mathrm{~m}$ a.s.l. to $55 \mathrm{~m}$ a.s.l., although slopes within the marsh do not exceed 1:3000.

The ground can be divided into three sectors:

- the first one, limited between 55 and $60 \mathrm{~m}$ a.s.l., corresponds to extensive areas with slow to very slow drainage, producing marshy and wetland environments, in which the water can frequently cover the ground from eight to nine months per year or more, depending on the intensity of rains and the microtopography;

- the second one, between the level curves of 60 $65 \mathrm{~m}$ a.s.l., includes the transition area, characterized 
by a matrix of shallow wetlands of tall and hard grasses, with sectors colonized by bushes and small forest settlements. Water residence time on the ground varies from four to six months;

- the third one, included between isohypsas of 65 and $70 \mathrm{~m}$ a.s.l., limits the highlands, constituted by soils of sandy texture, sieved by elliptic or subcircular lakes, which can have a connection with the lenitic environments, towards which they drain, as is the case of the Soto lake.

Mean depth recorded in Transection 1 (Figure 1) was $0.26 \mathrm{~m}$, with limit values between 0.15 and $0.40 \mathrm{~m}$. Transection 2 (Figure 1) presents a higher mean depth $(0.45 \mathrm{~m})$. The ground unevenness, between the inflow and outlet of the Soto marsh, is only $10 \mathrm{~cm}$.

\section{Soils}

Soto marsh occupies a flat-concave area between sandy hills which separate it from the Ambrosio stream. There are soils of different hydraulic conductivity, higher in the highest parts of the relief, occupied by grasslands.

Lowest sectors of the topographic gradient, which constitute small basins and remain as water pools during the low rain period, have very low hydraulic conductivity soils.

Soto marsh soils belong to three types: typical "Glosacualf", with a clay texture; typical "Albacualf", of a fine, clay-loam texture; and "abrupt Argiacuol", with a clay predominance.

Soto marsh has surface and illuvial horizons, with different characteristics:

- Surface horizons: they have medium textures (fine sandy loam), content of fine sand between $56-62 \%$, content of clay between $17-27 \%$, and high content of organic matter in the first $10-12 \mathrm{~cm}$ of the ground (4 and 6\%).

- Illuvial horizons: they have $40 \%$ or more clay, producing clay loam to clay textures; a moderately acid reaction on the surface, neutral to strongly alkaline in depth ( $\mathrm{pH} 8.5,9.1)$; low capacity of cationic exchange on surface and medium to high in horizons $\mathrm{B}_{2}$, and organic matter content lower than $1 \%$ below 25 $30 \mathrm{~cm}$ depth. These illuvial horizons are not permeable, with strong hydromorphism features. Effective depth for root penetration is $20-30 \mathrm{~cm}$.

\section{Vegetation}

The whole surface of the Soto marsh is permanently covered by herbaceous vegetation, adapted to waterloged soil conditions for 10 consecutive months, and also to prolonged droughts. Geophytes predominate at sites with semi permanent waters (Cyperus giganteus and Typha latifolia). The

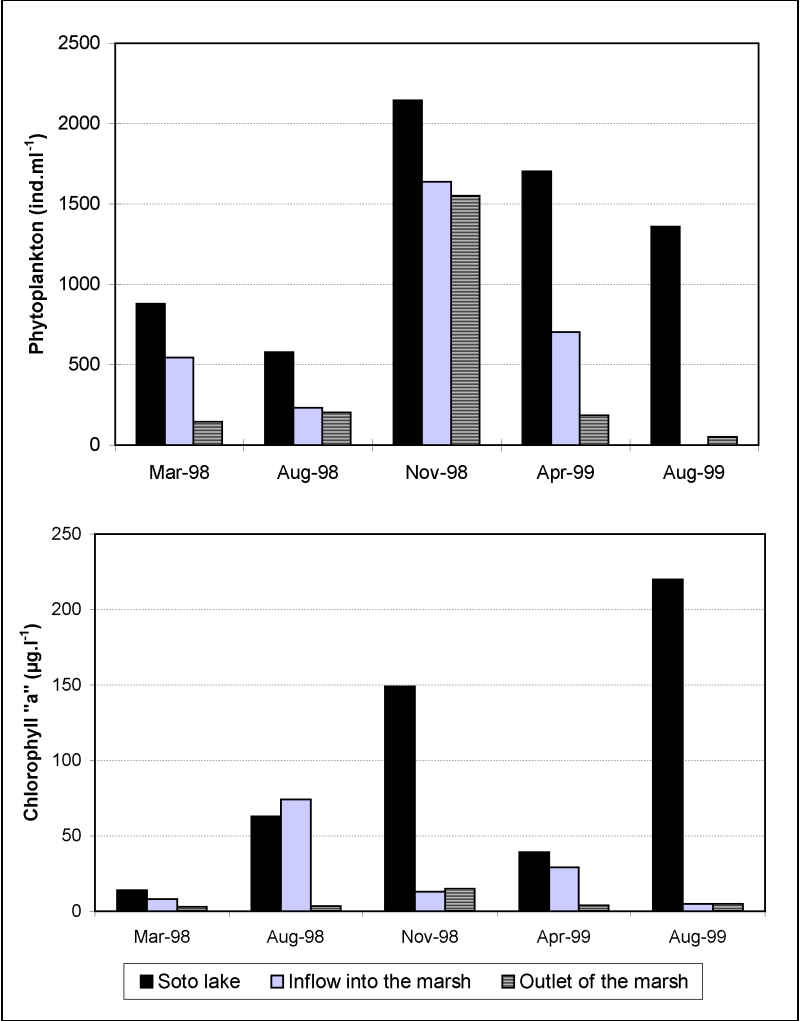

Figure 3. Phytoplankton density and chlorophyll "a" concentration at Soto lake and at Soto marsh.

largest surface is occupied by low and soft plants (Eleocharis acutangula; Paspalidium paludivagum, Oplismenopsis najada; $H y$ menachne amplexicaulis, Polygonum spp.). In the lowest parts, where there are permanent waters, there are submerged rooted plants (Egeria naias, Cabomba australis, Potamogeton pectinatus) and free floating plants (Salvinia biloba).

\section{RESULTS AND DISCUSSION}

Marshy vegetation is adapted to grow in flooded and frequently anaerobic soils. Plants transport oxygen from leaves to roots which constitute a dense rhizosphere, very important in the processes of nitrification-denitrification. Typha latifolia is one of the species with highest capacity to retain and degrade toxic substances (Gersberg et al., 1986; Hammer \& Bastian, 1989).

The scarce unevenness of low marshland areas and the dense herbaceous coverage produce an important delaying effect for rains coming from the highest sectors of the landscape (Mitsch \& Gosselink, 1993).

On the bottom of the marsh there is an organic matter layer of $2-6 \mathrm{~cm}$ depth which consumes the oxygen dissolved in the water and maintains reduction conditions. Its accumulation is due to the fact that the high production of marshy plants (15 to 22 t.ha $^{-1}$ year $^{-1}$; Neiff, 1981; Neiff, 2001) decomposes slowly. Although there have not been experiences of decomposition of organic matter carried 


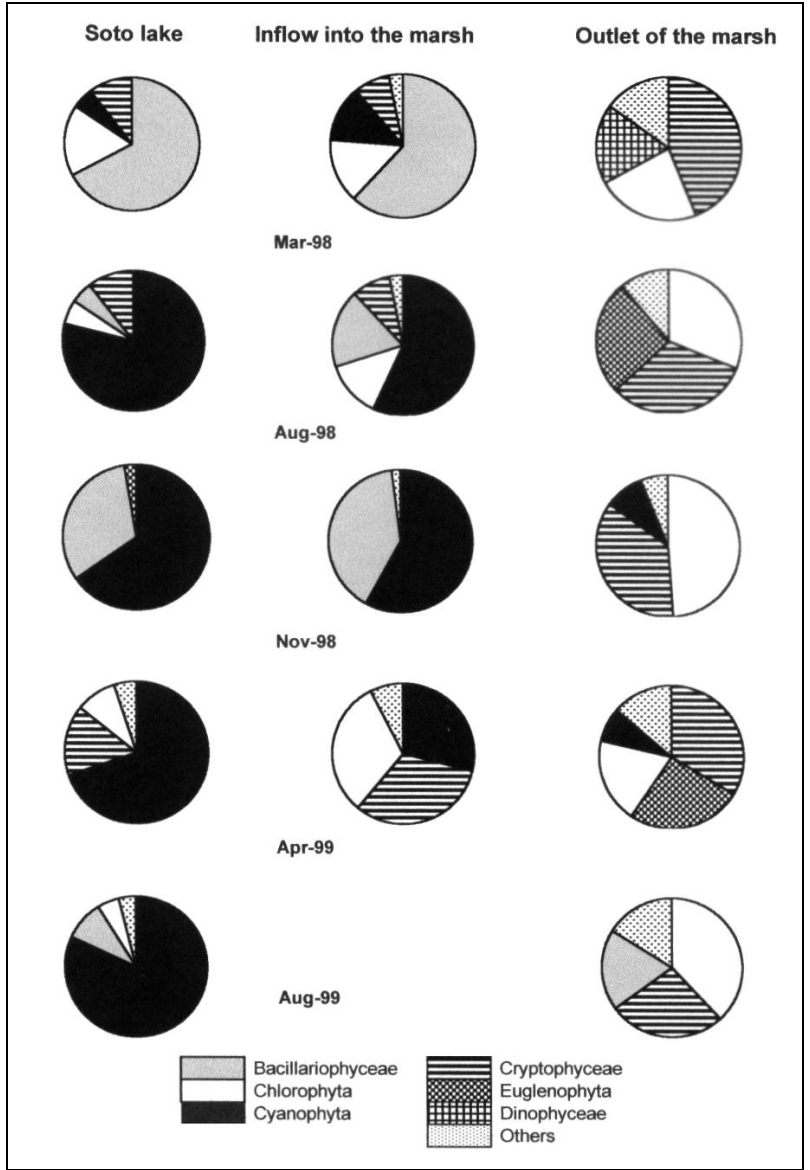

Figure 4. Relative abundance of the phytoplankton.

out in situ, in other wetlands located in the plain of the Paraná river, $100 \mathrm{~km}$ from this one, between 136 and 173 days have been estimated as necessary to degrade $50 \%$ of Typha latifolia leaves (Bruquetas \& Neiff, 1991; Bruquetas \& Poi de Neiff, 1993).

Water entering the marsh comes from Soto lake which trophic state was defined using the OECD (1982) boundary values for temperate lakes and the limit suggested by Thornton (1987) for phosphorus concentration in tropical lakes. This lake was considered eutrophic (Poi de Neiff et al., 1999) based on the mean and maximun chorophyll a concentration (86,3 and $220 \mu \mathrm{g} .1-1$ respectively) and the mean concentration of total phosphorus (77 $\mu \mathrm{g} . \mathrm{l}-1)$ and inorganic nitrogen (45 $\mu$ g.l-1). The low N:P ratio founded in Soto Lake is common in many tropical systems (Thornton, 1987) and lead to the dominance of cyanophytes.

In similar thermic conditions the water was more acid, had a lower salinity and lower concentration of dissolved oxygen (Figure 2) after circulating through the marsh vegetation, except in August 1999. At this time (prolonged drought), $\mathrm{pH}$ and the degree of dissolved oxygen were lower at the outlet than at the inflow of the marsh. Although the electric conductivity decreases in all samplings, reduction in the concentration of some anions and cations analyzed was only recorded during the prolonged rainy period (March, 1998, Table 1).

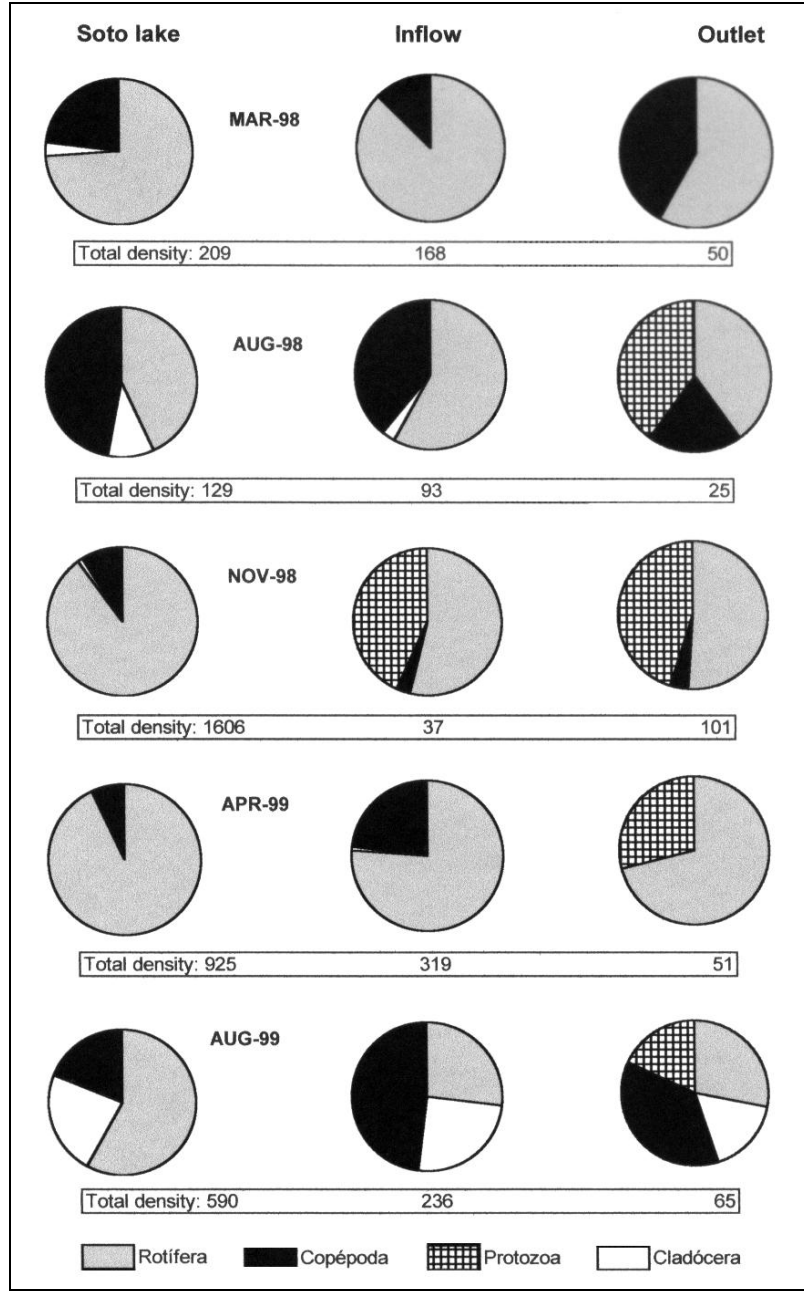

Figure 5. Relative abundance and density of zooplankton.

At the inflow, $\mathrm{BOD}_{5}$ values ranged between 3.3 and 14 mg..$^{-1}$ (Table 1). Passage through the marsh reduces $\mathrm{BOD}_{5}$ by $64 \%$, producing an average effluent of $2.2 \mathrm{mg} \cdot \mathrm{l}^{-1}$.

During the rainy period, the concentration of phosphorus was lower in the water leaving the system after passage through the marsh (Table 1), In this period phosphorus removal efficiencies were 66\% (March) and 60\% (Abril).

In the dry period, when a defficiency in dissolved oxygen was produced in the water (August and November 1998, Figure 2), total ammonium and phosphorus concentration increased in the water leaving the marsh (Table 1). Similar results were obtained in August 1999, when oxygen concentration in the water which enters the marsh decreased to $1.5 \mathrm{mg} . \mathrm{l}^{-1}$ (Figure 2 and Table 1). The correlation between ammonium concentration and oxygen content, measured with the Spearman coefficient, was -0.90 at inflow and -0.80 at outlet of the marsh. High denitrification rates occur in wetlands, even in those of cold areas, when levels of dissolved oxygen are lower than 2 $3 \mathrm{mg} . \mathrm{l}^{-1}$ (Stengel \& Schultz, 1989). Changes in availability of total phosphorus are due to the fact that, during the frequent periods of anaerobiosis in marshes, the ferric ion 


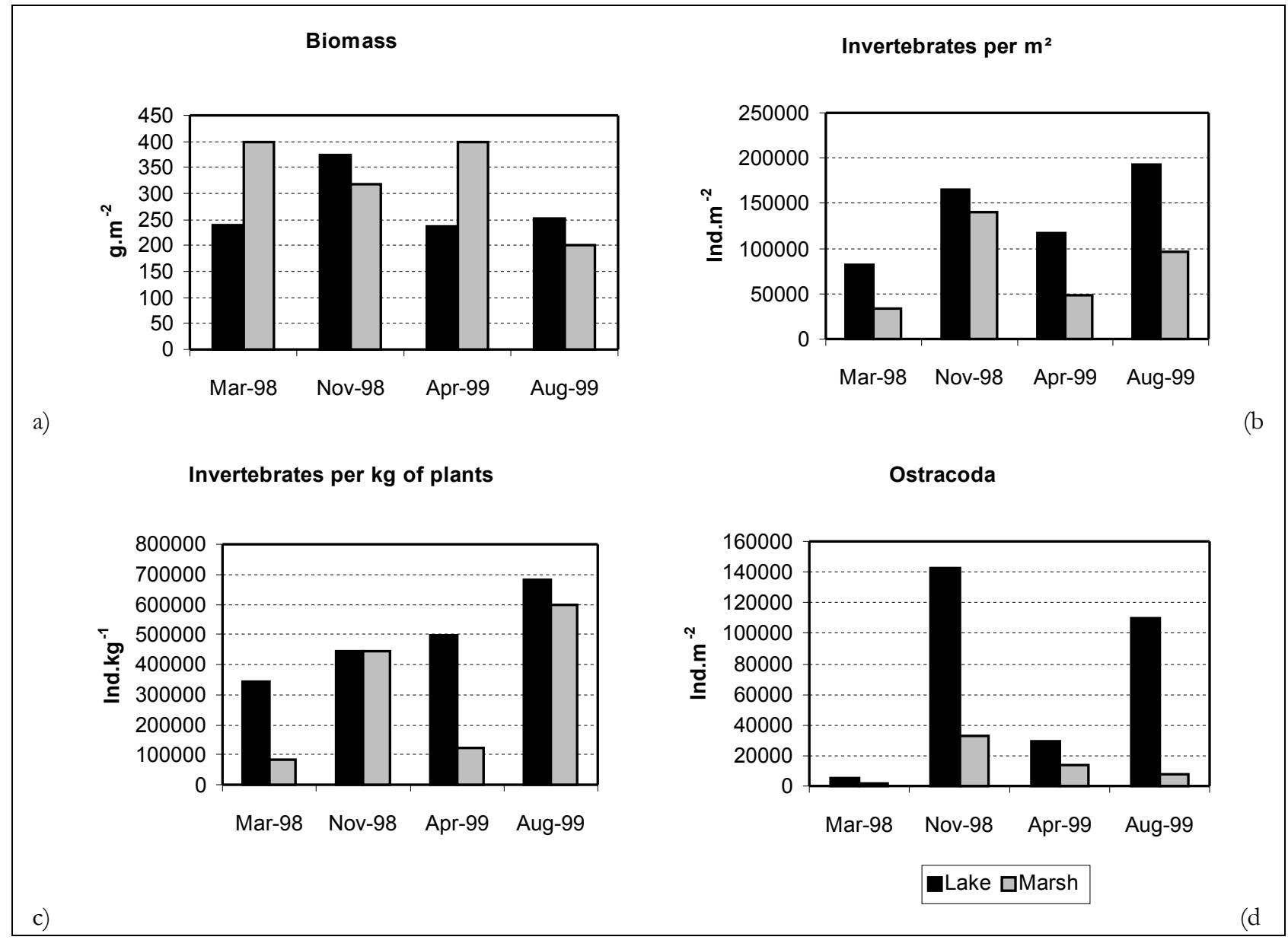

Figure 6. Variation in the Salvinia biloba biomass (a); in the number of invertebrates per $\mathrm{m}^{2}(\mathrm{~b})$; in the number of invertebrates per kg of dry weight of plants (c); and in the density of Ostracoda (d); standard deviation of mean values are minor than $20 \%$.

is reduced to its most soluble form (ferrous) and phosphorus remains in solution (Mitsch \& Gosselink, 1993). Changes in $\mathrm{pH}$ operated during water passage through the marsh are important to phosphorus availability, which in acid conditions, is liberated as phosphates (Carignan \& Vaithiyanathan, 1999).

Chlorophyll a concentration, used as an indicator of phytoplankton biomass, was high at the Soto lake, with a maximum value in August (Figure 3). This result is due to the abundance of colonies of Cyanophyceae in the phytoplankton (Figure 4). In samplings carried out at the marsh outlet, average chlorophyll concentration was reduces by $76 \%$ in relation to values recorded at inflow.

Quantitative analysis of phytoplankton (Figure 3) indicated that at marsh outlet the density was always less than at inflow, especially during rainy period. Differences in abundance of dominant groups of algae contribute to explain differences found in the results (Figure 4). In the Soto lake and at inflow of the Soto marsh, cyanophytes were dominant (Figure 4), specially colonies of Microcystis aeruginosa. Only in March 1998, Bacillariophyceae exceeded the rest of the algae in relative abundance (Figure 4). However, samples of this date correspond to a windy day after an intense rain, so that Aulacoseira granulata (Bacillariophyceae), not very frequent in surface waters, was abundant. At the marsh outlet there were qualitative and quantitative differences in relation to the inflow into the marsh, with a higher proportion of other algae (Clorophyta, Cryptophyceae, Euglenophyta, and/or Dinophyceae), depending on the collecting date (Figure 4).

Zooplankton abundance varied considerably among studied sites (Figure 5). Soto lake showed a dominance of rotifers, whose more abundant species are characteristic of eutrophic environments (Keratella cochlearis $\mathrm{f}$. tecta, Trichocerca similis and Brachionus havanaensis). In the marsh, these species decreased their abundance and were replaced by others adapted to the new limnological conditions. After passage through the marsh, protozoa (Difflugia spp. and Centropyxis sp.) and copepod nauplii had a higher relative abundance (Figure 5). Among the rotifers, the species of littoral areas (Lecane spp. and Bdelloidea) or those adapted to low oxygen concentrations, such as Filinea terminalis, were the most abundant ones.

Biomass of aquatic vegetation (Salvinia biloba with $O p$ lismenopsis najada, Hydrocleis nymphoides and Ceratophyllum demersum) varied between 200 and $400 \mathrm{~g} \cdot \mathrm{m}^{-2}$, with higher 
values in the marsh than in the lake during the rainy period (March 1998 and April 1999); however, in the dry period the relationship was inverted (Figure 6a).

Comparing the same vegetation, there was a decrease in the number of invertebrates per $\mathrm{m}^{2}$ which inhabit the aquatic plants of the marsh in relation to the lake (Figure $6 \mathrm{~b})$. Density of individuals per $\mathrm{kg}$ of dry weight of plants (Figure 6d) indicates that the reduction was real in the rainy period during which a decrease in the number of invertebrates was observed, even when there was a higher plant biomass per $\mathrm{m}^{2}$. This fact can be related with the washing of marsh vegetation during the water input. The relative abundance of the main groups of invertebrates associated with aquatic plants in the Soto lake (Figure 7) shows the high proportion of Ostracoda in most samplings, except in March 1998, in which Oligochaeta (Pristina sp., Dero (Aulophorus) carteri, Allonais paraguayensis and Slavina sawayai) were dominant. In November 1998 and August 1999 two ostracod populations, which had low density in the marsh, were very abundant in the Soto lake (Figure 6c). At the marsh outlet, there were changes in the invertebrate relative abundance, which were more marked in March 1998 (prolonged rainy period) and in August 1999 (prolonged dry period). In the first date, there was a high proportion of Hydrozetes sp. (Acari) and Suphisellus sp. (Noteridae), and in the second one, of Copepoda and larvae of Chironomus sp. group decorus, and Tanytarsus spp.

\section{CONCLUSIONS}

There are numerous records on the use of wetlands for treatment of effluents and many advantages (Ewel \& Odum, 1984; Gersberg et al., 1986; Hammer \& Bastian, 1989; Hsieh \& Coultas, 1989; Livingston, 1989; Mitsch et al., 1988; Ryding \& Rast, 1992) and low ecological costs are mentioned in relation to the capacity of wetlands to reduce contaminant charges, specially when they are of domestic origin.

Hydrological conditions of the Soto marsh are very favourable to chemical and biological removal from eutrophic waters: slow laminar circulation, scarce depth (10 to $70 \mathrm{~cm}$ ) and duration of the flood phase of approximately one month.

This expectation is limited because many wetlands function alternatively as sources or sinks of nutrients and this pattern depends on the hydrological conditions, the dissolved oxygen concentration in water and the season of macrophyte growth (Mitsch \& Gosselink, 1993).

Results obtained in the Soto marsh indicate that it functions as a source of nutrients (phosphorus and ammonium) when the concentration of organic matter is high and the depletion in the dissolved oxygen concentration is produced.

In the dry period, as well as in the rainy period, the chlorophyll a concentration, $\mathrm{BOD}_{5}$ values and total density of phytoplankton decreases after passage going through the marsh. Reduction in the concentration of phosphorus was only reccorded at rainy period. Rains produce two op-

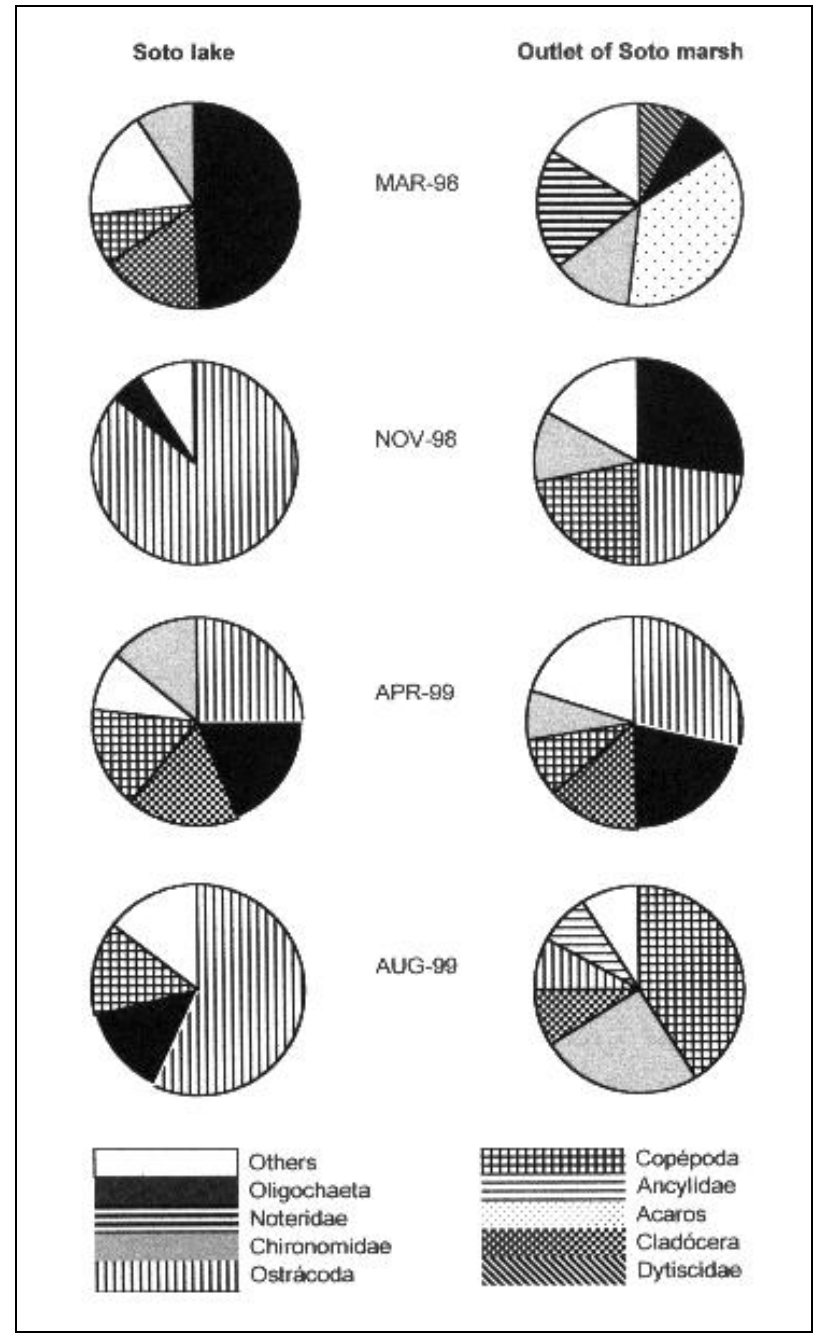

Figure 7. Relative abundance of invertebrates associated with aquatic plants at Soto lake and outlet of Soto marsh.

posite effects: dilution of chemical substances (including pollutants) and a more gradual outlet of charges existing in the Soto marsh. This hydrological functioning is common to many wetlands (Kadlec, 1989) and determines some difficulties to interpret the mass balance between chemical data at the inflow and outlet of the marsh.

Changes in plankton concentration of this wetland represent another variability complex. The effect of shading and the mechanical action of vegetation justify to a great extent the reduction of algae abundance, specially Cyanophyta, which maintain a high density in conditions of eutrophy in the Soto lake (Poi de Neiff et al., 1999). Algae, as well as zooplankton organisms, are also sensitive to water acidification and conditions of hypoxia recorded in the marsh.

Invertebrates living in vegetation acquire importance by constituting a main feeding source for fish, birds and other organisms (Poi de Neiff et al., 1999), specially in the dry periods of the marsh in which they reach 550,000 individuals per $\mathrm{kg}$ of dry weight of plants. 
Results obtained allow to revalue one of the multiple functions of wetlands in northeastern Argentina, which is the capacity of removing eutrophic water. Moreover, these results evidence the need of carrying out long term investigations on this subject since the greatest part of studies referred to wetlands use for treatment of domestic wastes were conducted for relatively short periods of time (Whigham, 1982; Gopal, 1998).

\section{ACKNOWLEDGEMENTS}

To Ing. J. J. Lugo, from the Agricultural-Meteorology Division of the INTA Bella Vista (Corrientes), for providing us the rain data. To Prof. A. O. Ramos and to Mr. Julio Cáceres for providing technical assistance in the chemical analysis of water.

\section{REFERENCES}

APHA - American Public Health Association; AWWA American Water Works Association; WEF - Water Environment Federation (1975). Standar methods for the examination of water and wastewater. 14th edition. Eaton, A. D.; L. S. Clesceri y A. D. Greenberg (eds.). Washington.

BASTIAN, R. K.; SHANAGAN, P. E. \& THOMPSON, B. (1989). Use of wetlands for municipal wastewater treatment and disposal regulatory issues and EPA policies. In: D. A Hammer (ed): Constructed Wetlands, p.265-275.

BRINSON, M.; SWIFT, M. B.; PLANTICO, R. C. \& BARCLAY, J. S. (1981). Riparian ecosystems: their ecology and status. USFWS (FWS/OBS 81/17), Washington, p.1-151.

BRUQUETAS DE ZOZAYA, I. Y. \& NEIFF, J. J. (1991). Decomposition and colonization by invertebrates of Typha latifolia L. litter in Chaco cattail swamp (Argentina). Aquatic Botany, 40: 185-193.

BRUQUETAS DE ZOZAYA, I. Y. \& POI de NEIFF, A. (1993). Descomposición de macrófitos en bañados de la planicie inundable del río Paraná. Ambiente Subtropical, 3: 1-17.

CARIGNAN, R. \& VAITHIYANATHAN, P. (1999). Phosphorus availabity in the Paraná floodplain lakes (Argentina): Influence of $\mathrm{pH}$ and phosphate buffering by fluvial sediments. Limnol. Oceanogr., 44 (6):1540-1548.

DOWNING, J. A. \& CYR, H. (1985). Quantitative estimation of epiphytic invertebrate populations. Can. J. Fish Aquat. Sci. 42: $1570-1579$

EWEL, K. C. \& ODUM, H. T. (eds) (1984). Cypress swamps. University Press of Florida. Gainesville, Florida. 472p.

GERSBERG, R. M.; EKINS, B. V.; LYON, S. R. \& GOLDMAN, C. R. (1986). Role of aquatic plants in wastewater treatment by artificial wetlands. Water Res. 20: 363-368

GIOVANNINI, S. G. T. \& MOTTTA MARQUES, D. M. L. (1998a). O uso de subsolo como substrato para construção de banhados com macrófitas aquáticas emergentes sob diferentes regimes hídricos. Acta Limnologica Brasiliensia, 10 (2): 71-81.

GIOVANNINI, S. G. T. \& MOTTA MARQUES, D. M. L. (1998b). Conditioning factors for establishment of Zizaniopsis bonariensis in constructed wetlands. Proc. $6^{\text {th }}$.
Int. Conf. on Wetland Systems for Water Pollution Control, p.559-563.

GOPAL, B. (1998). Natural and constructed wetlands for wastewater treatment: potentials and problems. Proc. $6^{\text {th }}$. Int. Conf. on Wetland Systems for Water Pollution Control, p.54-69.

HAMMER, D. A. \& BASTIAN, R. K. (1989). Wetlands ecosystems: natural water purifiers?, 5-20. In: D. A. Hammer (ed.): Constructed Wetlands. Lewis Publ., 1-831.

HEY, D. L.; CARDAMONE, M. A.; SATHER, J. A. \& MITSCH, W. J. (1989). Restoration of riverine wetlands: the des plaines river wetlands demonstration project. 159-184, In: Mitsch, W. J. \& S. E. Jorgensen. Ecological Engineering. Wiley\&Sons, 1-472

HSIEH, Y. P. \& COULTAS, C. L. (1989). Nitrogen removal from freshwater wetlands: Nitrification-denitrification coupling potential, 493-500. In: D. A. Hammer (ed.): Constructed Wetlands. Lewis Publ., 1-831.

KADLEC, R. H. (1989). Hydrologic factors in wetland water treatment. 21-40 In: D. A. Hammer (ed.): Constructed Wetlands. Lewis Publ., 1-831.

LIVINGSTON, E. H. (1989). Use of Wetlands for Urban Srormwater Management. 253-264. In: D. A. Hammer (ed.): Constructed Wetlands. Lewis Publ., Michigan. 831p.

MITSCH, W. J. \& GOSSELINK, J. G. (1993). Wetlands. Van Nostrand Reinhold Publ. New York. 1721p.

MITSCH, W. J.; STRASKRABA, M. \& JORGENSEN, S. E. (1988). Wetland Modelling. Elsevier, p.1-227.

NEIFF, J. J. (1981). Panorama ecológico de los cuerpos de agua del nordeste argentino. Symposia, VI Jornadas Argentinas de Zoología, La Plata: 115-151.

NEIFF, J. J. (1997). El régimen de pulsos en ríos y grandes humedales de Sudamérica, 1-49. In: Malvarez, A. I. y P. Kandus (eds.): Tópicos sobre grandes humedales sudamericanos. ORCYT-MAB (UNESCO), 1-106.

NEIFF, J. J. (2001). Diversity in some tropical wetland systems of South América: 157-186. In: Biodiversity in wetlands: assessment, function and conservation. Vol. II. B. Gopal \& W. Junk (Eds.), Backhuys Publish. 311p., The Netherlands.

NUÑEZ, M. N. \& VARGAS, W. M. (1998). El niño 1997-1998: un factor económico y social. Techint, Boletín Informativo $\mathrm{n}^{\circ} 295,28 \mathrm{p}$.

OECD (1982). Eutrophication of waters. Monitoring, assessment and control. Final Report. París. 154p.

POI DE NEIFF, A.; NEIFF, J. J.; PATIÑO, C. A.; RAMOS, A. O.; CACERES, J. R.; FRUTOS, S. M. \& CANON VERON, M. (1999). Estado trófico de dos lagunas en planicies anegables con áreas urbanas. Rev. Facena, 15: 93-110.

RYDING, S. \& RAST, W. (1992). El control de la eutrofización en lagos y pantanos. Ed. Pirámide, Madrid. 375p.

SALATI, E.; SALATI, E. \& SALATI FILHO, E. (1998). Project of wetlands developed in Brazil. Proc. $6^{\text {th }}$. Int. Conf. on Wetland Systems for Water Pollution Control: p.11-26.

STEEL, R. \& TORRIE, J. H. (1985). Estadística: principios y procedimientos. Mc Graw-Hill. Bogotá. 622p.

STENGEL, E. \& SCHULTZ, R. (1989). Denitrificatión in artificial wetlands. In: Hammer, D. (ed.): Constructed wetlands for wastewater treatment. Lewis Publ. Michigan: 486-492.

THORNTON, J. A. (1987). Aspects of eutrophication management in tropical subtropical regions. J. Limnol. Soc. Sth. Afr.,13 (1): 25-43. 
UHTERMOL, H. (1958). Zur Vervollkomnung der quantitativen Phytoplankton Methodik. Mitt. Int. Ver. Limnol., 9: 1-38.

WATSON, J. T. \& HOBSON, J. A. (1989). Hydraulic desing consideration and control structures for constructed wetlands for wastewater treatment. In: Hammer, D (ed). Constructed wetlands for wastewater treatment. Lewis Publ. Michigan.

WHIGHAM，D. F. (1982). Using freshwater wetland for wastewater management in North America. In: Gopal et al. (eds.): Wetlands, ecology and management. National Institute of ecology. Nueva Delhi. 507-514.

\section{Resposta de um Banhado Natural às Contribuiçôes Químicas e Biológicas de Águas Eutróficas (Saladas, Corrientes, Argentina)}

\section{RESUMO}

O banhado de Soto é uma área de terras úmidas interiores, sem a presença de florestas, com um clima subtropical úmido, alimentado por chuvas e resíduos domésticos através do lago Soto. São descritas as principais características hidrológicas e a composição da vegetação e do solo através dos quais circula a água. Foram comparadas as condições químicas e biológicas das águas que entram e saem do banhado durante periodos secos e chuvosos. A passagem através do banhado redur a DBO5 em 64\%, produrindo um efluente médio de 2,2 $\mathrm{mg} / \mathrm{l}$. A concentração média de clorofila a foi redurida em $76 \%$ em relação ao valor registrado no ponto de entrada. Durante o período chuvoso, a concentração de cloretos, cálcio, potássio e sódio era mais baixa na saída do banbado, enquanto que, no periodo seco, a concentração de ânions e cátions era muito variável. Os nossos resultados indicam que o banhado de Soto funcionava como uma fonte de nutrientes (fósforo e amônia) quando a concentração de matéria orgânica era elevada e a concentração de oxigênio dissolvido era baixa. No lago Soto, e no ponto de entrada ao banhado de Soto, o fitoplâncton era dominado por cianofitas, especialmente colônias de Microcystis aeruginosa, enquanto que, na saída do banhado, havia uma proporção mais elevada de outras algas. Após passar através do banhado, diminuia a abundância de rooplâncton, especialmente as populações de rotiferas características de ambientes eutróficos. Comparando a mesma vegetação (Salvinia biloba), o numero de invertebrados associados às plantas era mais elevado no lago do que no banhado. Esta diminuição era mais acentuada durante o período de chuvas.

Palavras-chave: banhado; contribuições; químico; biológico. 